\title{
Nobelpris for studier av vesikkeltransport
}

Cellene i kroppen skiller ut proteiner til sine omgivelser. Hvor mye og hvilke proteiner varierer med celletype, men alle proteiner som skal til cellemembranen for utskilling følger prinsipielt den samme sekretoriske veien fra det endoplasmatiske retikulum, der de kobles sammen av aminosyrer, via golgiapparatet til celleoverflaten. At proteiner som lages sentralt $i$ cellen tar denne veien til plasmamembranen, ble påvist av en av cellebiologiens pionerer, George Palade (nobelprisen i 1974), og hans medarbeidere. Årets nobelpris i fysiologi eller medisin ble tildelt forskere som har arbeidet med cellulære transportmekanismer. James E. Rothman, Randy W. Schekman og Thomas C. Südhof har vist hvordan et maskineri av cellens egne proteiner styrer danning og avsnøring av vesikler fra en donormembran og deres fusjon med en mottakermembran (1-4). Proteinmaskineriet settes sammen av spesifikke, men beslektede komponenter for hvert transportsteg, slik at spesifisiteten ivaretas, ved at én type transportvesikler leverer sitt innhold ved fusjon med en bestemt målmembran. Vesiklene kan ha diameter i underkant av 100 nanometer, men også større transportbeholdere er observert. Alle er omsluttet av en membran med et dobbelt lipidlag, slik enhver membran i cellene våre er bygd opp. Proteinene som skal transporteres er enten løselige i lumen av vesiklene eller de har en forankring i vesikkelmembranen. De sistnevnte blir til overflateproteiner når vesiklene som forestår det siste transporttrinnet fusjonerer med cellemembranen. Blant slike proteiner finner vi reseptorer for LDL og for epidermale og andre vekstfaktorer.

Alle prisvinnerne er aktive forskere i dag, men de banebrytende oppdagelsene til grunn for tildelingen ble gjort langt tilbake i tid. Schekman (f. 1948) studerte i Los Angeles og tok sin ph.d. ved Stanford University, før en postdoktorperiode i San Diego, men har vært ansatt ved Berkeley siden midten av 1970-årene, da han startet sin studie av gener som er nødvendige for sekretorisk transport i gjærceller. Ved å generere en rekke tilfeldige gjærmutanter kunne man velge å studere de som fikk nedregulert sekresjon, for deretter å bestemme hvilke gener som var slått av.

Rothman (f. 1950) studerte ved Yale University, tok sin ph.d. ved Harvard og var postdoktor ved Massachusetts Institute of Technology. I 1978 innledet han et produktivt tiår ved Stanford University, før han returnerte til østkysten (Princeton), og er nå tilbake ved Yale. Han og hans medarbeidere studerte pattedyrceller og valgte en tyngre vei - å isolere proteiner som er avgjørende for vesikkeltransport. Fra det første proteinet (NSF) var isolert, kunne de nøste videre hvilke proteiner NSF samarbeidet med (SNAP, SNARE m.fl.), og etter hvert kunne man også forstå deres mekanistiske sammenheng. Det var i mange tilfeller overensstemmelse mellom de proteinene Rothman studerte i pattedyrceller og de genene Schekman studerte i gjærceller, noe som understreket viktigheten av de identifiserte komponentene.

Thomas Südhof (f. 1955) er født i Göttingen og studerte medisin ved universitetene i Aachen, Harvard og Göttingen frem til 1982, da han leverte sin doktoravhandling. Deretter flyttet Südhof til Dallas som postdoktor hos Brown og Goldstein (nobelprisvinnere i 1985), før han i 1986 ble selvstendig forsker. Siden 2008 har han vært ansatt ved Stanford University. Südhof valgte å studere vesikler som er nødvendige for at transmittorsubstanser skal kunne frigjøres fra presynaptiske nerveceller. Südhof og hans medarbeidere identifiserte spesifikke komponenter for vesikkeltransport i nerveceller som fungerer på samme måte som de generelle mekanismene i alle celler. De påviste også betydningen av kalsiumioner og hvordan endringer i deres intracellulære konsentrasjon påvirker fusjon av vesikler til mottakermembranen. Det er nok Südhofs arbeid som lettest kan knyttes til bedre forståelse og behandling av sykdommer, blant annet ved nevrodegenerative lidelser. Han har i tillegg publisert arbeider som kan øke forståelsen av autisme og schizofreni. Südhof avslørte også virkningsmekanismene til tetanus- og botulismetoksinene som spalter proteiner som er essensielle for fusjon av vesikler med den presynaptiske plasmamembranen.

Kontroll over den sekretoriske vei er også viktig ved produksjon av legemidler av proteinnatur. En tredel av insulinet og all hepatitt B-vaksine som selges i dag produseres i gjærceller. Men mange proteiner av farmasøytisk interesse kan ikke produseres i gjærceller (eller bakterier) hvis de skal kunne brukes terapeutisk. Flertallet av proteinene i kroppen modifiseres videre etter at de er koblet sammen av aminosyrer etter oppskriften i budbringer-RNA, som igjen er en avlesning av DNA. Den vanligste blant mange ulike posttranslasjonelle modifikasjoner er glykosylering, der enzymer kobler en rekke sukkerenheter til proteinet. Også immunoglobuliner er glykosylert, og strukturen av sukkerdelen er viktig for aktiviteten. Mange proteiner må derfor uttrykkes i pattedyrceller, eller til og med i humane cellesystemer for å oppnå de modifikasjoner som gir den ønskede virkningen.

Selv om man i dag har god kunnskap om hvilke modifikasjoner proteiner er gjenstand for i den sekretoriske vei, er det fortsatt uklart hvordan transportveien er organisert. Det sentrale organellesystemet, golgiapparatet, har en dynamikk som er forsøkt forklart med minst fem ulike modeller.

Årets nobelprisvinnere har vunnet priser før. Mens Rothman og Schekman delte Albert Lasker-prisen i 2002, fikk Südhof denne i år sammen med Richard Scheller. Rothman, Südhof og Scheller delte Kavli-prisen i 2010. Det er bred enighet om at de tre forskerne fortjener nobelprisen. Schekman uttrykte likevel overraskelse, fordi det hadde gått lang tid siden de mest fundamentale oppdagelsene ble gjort i dette feltet. Ved å se 10-15 år bakover på kandidatlisten kan man også få inntrykk av at de mest grunnleggende oppdagelsene har tapt noe terreng i forhold til oppdagelser man lettere kan tilskrive en medisinsk eller samfunnsmessig nytte. For tilhengere av grunnforskning er årets tildeling desto mer gledelig.

Kristian Prydz

kristian.prydz@ibv.uio.no

Kristian Prydz (f. 1958) er dr.scient. i biokjemi og professor ved Institutt for biovitenskap, Universitetet i Oslo.

Forfatter har fylt ut ICMJE-skjemaet og oppgir ingen interessekonflikter.

Litteratur

1. Balch WE, Dunphy WG, Braell WA et al. Reconstitution of the transport of protein between successive compartments of the Golgi measured by the coupled incorporation of N-acetylglucosamine. Cell 1984; 39: 405-16.

2. Novick P, Schekman R. Secretion and cell-surface growth are blocked in a temperature-sensitive mutant of Saccharomyces cerevisiae. Proc Natl Acad Sci U S A 1979; 76: 1858-62.

3. Hata Y, Slaughter CA, Südhof TC. Synaptic vesicle fusion complex contains unc-18 homologue bound to syntaxin. Nature 1993; 366: 347-51.

4. Kaiser CA, Schekman R. Distinct sets of SEC genes govern transport vesicle formation and fusion early in the secretory pathway. Cell 1990; 61: 723-33. 